\title{
THE WORLD OF INNOVATION
}

https://doi.org/10.15407/scine17.04.089

MELNYK, O. P.' (https://orcid.org/0000-0002-9177-8904),

GALIMOVA, V. M.2 (https://orcid.org/0000-0001-9602-1006),

RADZIEVSKA, I. G.' (https://orcid.org/0000-0002-6081-0625),

and MARYNIN, A. I.' (https://orcid.org/0000-0001-6692-7472)

'National University of Food Technologies,

68 , Volodymyrska St., Kyiv, 01033, Ukraine,

+380 44289 5472, info@nuft.edu.ua

${ }^{2}$ National university of Life and Environmental Sciences of Ukraine,

15, Heroiv Oborony St., Kyiv, 03041, Ukraine,

+380 445278242 , rectorat@nubip.edu.ua

\section{APPLICATION OF THE INVERSE CHRONOPOTENTIOMETRY METHOD TO CONTROL THE CONTENT OF TOXIC ELEMENTS IN REFINING PRODUCTION}

Introduction. Ukraine is one of the world leading exporters of sunflower oil. An important safety indicator is the content of toxic elements in it, which should not exceed the maximum permissible concentrations. Toxic elements entering the human body reduce the functions of individual systems and organs and lead to immunodeficiency.

The toxic elements by which food products are controlled include copper (Cu), zinc ( $\mathrm{Zn}$ ), iron (Fe), cadmium $(\mathrm{Cd})$, lead $(\mathrm{Pb})$, arsenic $(\mathrm{As})$, and mercury $(\mathrm{Hg})$.

Problem Statement. Despite a significant progress in the physico-chemical methods of analysis, their determination in raw materials, semi-finished products, and food products causes many difficulties.

Purpose. The purpose of this research is to compare the inverse chronopotentiometry (IChP) and the atomic absorption methods while determining the content of toxic elements in sunflower oil at different stages of the technological process of its production.

Materials and Methods. Sunflower oil obtained by pressing and extraction as well as a mix of pressed and extracted oil of different degrees of purification: hydrated, neutralized, winterized, and refined deodorized have been used for the study by the IChP and the atomic absorption methods. When determining the concentration of toxic elements by the IChP method, the duration of inversion of the anodic dissolution of metal ions that are previously accumulated during electrolysis on the surface of the indicator electrode has been determined.

Results. The analysis of oil samples has shown that they all contain toxic elements, the concentration of which decreases at each stage of oil production and does not exceed the permissible levels as established by regulations.

Conclusions. The obtained data create preconditions for wide introduction of the IChP method in refining production, inasmuch as this method allows determining the content of toxic elements in vegetable oils with a high convergence of results - lin relation to the conventional method of atomic absorption.

Keywords: sunflower oil, production stages, toxic elements, inversion and chronopotentiometry.

Citation: Melnyk, O. P., Galimova, V. M., Radzievska, I. G., and Marynin, A. I. Application of the Inverse Chronopotentiometry Method to Control the Content of Toxic Elements in Refining Production. Sci. innov. 2021. V. 17, no. 4. P. 89-96. https://doi.org/10.15407/scine17.04.089 
The EU-Ukraine Association Agreement has created big opportunities for further development of agribusiness in Ukraine and opening of the EU market for Ukrainian goods. Today, Ukraine is one of the world leaders in sunflower oil export. According to 2019, the Ukrainian export of this product reached $60 \%$ of the world market [1-3].

An important indicator for sunflower oil is content of toxic elements, which should not exceed the maximum permissible concentration (MPC) [4].

Toxic elements are related to widely-known contaminants. They are widespread in different industries and agriculture therefore they exist mainly in the form of various compounds rather than as independent elements. Because of their physicochemical properties (valence, solubility, and others), the toxic elements have different migratory capacity in the food chain [5-7]. Having entered the human body, they slowly reduce the functions of certain systems and organs, lead to immunodeficiency, and cause mutagenic, teratogenic, and embryotoxic effects [8], and therefore the determination of toxic elements in food is an urgent problem.

According to the requirements for the quality and safety of food and raw materials, the toxic elements by which food is controlled, include copper, zinc, iron, cadmium, lead, arsenic, and mercury [9].

Copper $(\mathrm{Cu})$ is a vital element that is part of many enzymes, hormones, vitamins, respiratory pigments, is involved in metabolic processes, tissue respiration, and so on. It is important to maintain the normal structure of bones, cartilage, tendons (collagen), the elasticity of the walls of blood vessels, pulmonary alveoli, skin (elastin). $\mathrm{Cu}$ is present in the body's antioxidant defense system, has pronounced anti-inflammatory properties [10].

On the other hand, $\mathrm{Cu}$ is a highly toxic element capable of causing acute poisoning, which has a broad spectrum of action with many clinical manifestations. The ability of its ions to block SHgroups of proteins, especially enzymes, plays a crucial role in the mechanism of toxic action of this element [11].
Zinc $(\mathrm{Zn})$ is part of numerous enzymes; it is a low-toxic element. However, an excess of zinc in the body leads to increased blood $\mathrm{pH}$ and renal function disorder, inflammation of the mucous membrane of the nose and nasopharynx, labored respiration $[12,13]$.

Iron $(\mathrm{Fe})$ is involved in the transport and storage of oxygen, DNA synthesis, protein metabolism, synthesis of thyroid hormones, production of connective tissue, neurotransmitters, plays an important role in maintaining immunity. It is a part of cytochromes that take an active part in the processes of accumulation of energy in cells of an organism.

However, an excess of Fe in the body can damage the brain, kidneys, and liver. Its main symptoms are yellowish skin, enlarged liver, arrhythmia, pigmentation of the skin and others. [14].

Lead $(\mathrm{Pb})$ is not a vital element. It is toxic and belongs to the $1^{\text {st }}$ class of hazard. Its inorganic compounds disrupt metabolism and are inhibitors of enzymes (like most toxic elements). The ability to replace calcium in bones and be a constant source of poisoning for a long time is considered one of the most insidious properties of inorganic compounds of lead [15].

Cadmium $(\mathrm{Cd})$ and its compounds enter the human body over a long period, and are excreted very slowly, from 10 to 30 years. Once in the human body, Cd has a negative effect on the liver, kidneys, central nervous system, disrupts the phosphorus-calcium metabolism. In addition, its compounds are potent carcinogens [16].

Arsenic (As) causes damage to capillaries in the body and has a direct toxic effect on certain organs. Pathological changes in the case of arsenic poisoning are characterized by necrosis of the stomach and small intestine, vascular and degenerative changes in the liver and kidneys. The mechanism of toxic action of As is associated with the blockade of SH-groups of proteins and enzymes that perform various functions in the body [17].

Mercury ( $\mathrm{Hg}$ ) is one of the most dangerous and highly toxic elements that can accumulate in plants, animals, and humans. Contamination of food pro- 
ducts with mercury can occur through the natural process of its evaporation from the earth's crust in the amount of 25000-125000 tons per year. The mechanism of toxic action of mercury is realized primarily through the interaction with thiol groups of proteins. It blocks them and changes the properties or inactivates a number of vital enzymes. Zinc and selenium have a protective effect against the effects of mercury on the human body [18].

Statement of the problem. Despite a significant progress in the physico-chemical methods of analysis, the determination of toxic elements in raw materials, semi-finished products, and food products is associated with many difficulties [19-22].

Traditionally, the method of atomic absorption with the help of a graphite furnace is used [23, 24]. The method is based on the ability of atoms of toxic elements to selectively absorb electromagnetic radiation in different parts of the spectrum. In the course of the method implementation, through the layer of atomic vapors of the sample obtained by the atomizer, radiation in the range of $190-850 \mathrm{~nm}$ is transmitted. As a result of the absorption of light quanta, atoms get excited. These transitions in the atomic spectra correspond to the characteristic resonant lines of this element.

At a certain wavelength that corresponds to the optical transition of the atom from the ground state to the excited level, the absorption of radiation leads to a decrease in the population of the ground level. The analytical signal quantity is related to the concentration of atoms in the ground state and, therefore, to the concentration of the element in the analyzed sample. By measuring the proportion of absorbed electromagnetic radiation, the content of the analyte is quantified [25, 26].

The disadvantages of this method are a significantly long duration of analysis, the use of highcost and hard-to-maintain equipment (atomic absorption spectrophotometer equipped with air-acetylene torch, graphite furnace fluffer, background absorption corrector, and sources of resonant radiation of light metals), toxic and fire accelerants (cyclohexane, acetylene) and the necessity to ma- ke measurements of toxic elements in the laboratory with special equipment.

An alternative to the atomic absorption method is the method of inversion chronopotentiometry (IChP). The advantages of this method include high accuracy and sensitivity in the analysis, the ability to determine the concentration of toxic elements with a minimum number of preparatory operations, automation and computerization of analysis processes; inexpensive equipment that is ten times cheaper than the cost of atomic absorption analyzer [25, 27-29].

The purpose of the research is to compare the IChP technique with the atomic absorption method while determining the content of toxic elements in sunflower oil at different stages of the technological process of its production.

\section{Presentation of the material}

Materials and methods. The study has been carried out with the use of sunflower oil obtained by pressing and extraction methods and a mix of pressed and extracted oils having different degrees of purification: hydrated, neutralized, winterized, and refined deodorized ones.

When measuring the concentration of toxic elements by the IChP method, we have determined the duration of inversion of the anodic dissolution of metal ions previously accumulated during electrolysis on the surface of the indicator electrode. Depending on the level of MPC, the sample concentration time is set. Based on the obtained values of potentials and inversion time, the computer program automatically builds a chronopotentiogram of inversion, where the qualitative characteristic of the metal is its inversion potential, and the quantitative characteristic is the inversion time [30, 31].

The oil samples for analysis are prepared according to [32] by the method of complete decomposition of organic substances by mineralization of raw material samples in a muffle furnace. The method involves the preparation of samples for atomic absorption spectrophotometry and polarography, which includes the IChP modern method. 
To do this, a small amount of $2-3 \mathrm{~cm}^{3}$ concentrated nitric acid is added to a $25 \mathrm{~cm}^{3}$ oil sample and charred in an electric stove. After charring the sample, it is mineralized in a muffle furnace.

The samples are mineralized gradually, at a heating rate of the muffle furnace $50^{\circ} \mathrm{C}$ every $30 \mathrm{~min}$, up to $550{ }^{\circ} \mathrm{C}$, to obtain a white ash without charred parts. The possibility of loss of the studied elements because of the formation of volatile compounds in the process of ash formation is not controlled, since 2 parallel measurements are performed for different methods.

The resulting ash is dissolved in the background electrolyte (2n HCl solution). After complete dissolution of the ash, the solution is filtered through an ashless filter, pre-washed with the background electrolyte. Since the content of mercury and lead in real samples is insignificant, no precipitation is observed during the dissolution of ash in hydrochloric acid, and at a given concentration potential, metal ions from the solution move to the surface of the measuring or the indicator electrode.

To determine toxic elements experimentally, the reference (background) solution $(2 \mathrm{n} \mathrm{HCl}$ solution) is analyzed and the inversion time $\tau_{\phi}$ on the M-HA1000-5 device in the Additives method mode is determined. The measurement is done on a solid silver electrode coated with mercury amalgam, with an auxiliary silver chloride electrode at given electrochemical parameters of electrolysis.

In order to determine the inversion time of the sample $\tau_{\text {II }}$ the ash solution is studied. Further, an additive of a reference metal ions sample (one or more additives) is added to the sample and the inversion time of the sample with the additive is determined $\tau_{\text {п }}$.

Based on the obtained inversion time of the background, the sample, and the sample with the additives, the mass concentration of toxic element in the oil is determined according to [33]:

$$
C=k \cdot m \cdot \frac{\tau_{\text {пI }}-\tau_{\phi}}{\tau_{\text {д }}-\tau_{\text {п }}},
$$

where $C$ is metal concentration, $\mathrm{g} / \mathrm{dm}^{3} ; k$ is the coefficient of translation of the electrolyzer solution concentration into the corresponding concentration in $1 \mathrm{~g} / \mathrm{dm}^{3}$ water sample; $m$ is the mass of the additive of metal ion solution reference sample, g.

The toxic element concentration is determined separately for each metal because of their different MPC in the oil and different background solutions for measuring toxicants.

Thus, the content of cadmium, copper, mercury, arsenic, lead, iron, and zinc has been determined by atomic absorption (Table 1) and IChP (Table 2) methods at different stages of sunflower oil production, where sample 1 is pressed, 2 is extracted, 3 is hydrated, 4 is neutralized, 5 is winterized, and 6 is deodorized oils.

Sample 1 and sample 2 are samples obtained from sunflower seeds of standard quality with the use of fundamentally different methods. Samples 3,4 , and 5 are taken during the oil refinement, after oil processing according to the appropriate modes. The refining process consists of hydration,

Table 1. Concentration of Toxic Elements in Sunflower Oil, as Determined by the Atomic Absorption Method

\begin{tabular}{|c|l|l|l|l|l|l|l|}
\hline \multirow{2}{*}{ Element } & \multirow{2}{*}{$\begin{array}{c}\text { MPC, } \\
\mathrm{mg} / \mathrm{kg}\end{array}$} & \multicolumn{6}{|c|}{ Content of toxic elements, mg/kg } \\
\cline { 3 - 8 } & & 1 & 2 & 3 & 4 & 5 & 6 \\
\hline $\mathrm{Cd}$ & 0.05 & 0.056 & 0.055 & 0.041 & 0.033 & 0.026 & 0.021 \\
$\mathrm{Cu}$ & 0.5 & 0.520 & 1.280 & 0.140 & 0.315 & 0.180 & 0.120 \\
$\mathrm{Hg}$ & 0.03 & 0.0064 & 0.0068 & 0.0019 & 0.0021 & 0.0016 & 0.0012 \\
$\mathrm{As}$ & 0.1 & 0.065 & 0.070 & 0.065 & 0.0055 & 0.0015 & 0.0010 \\
$\mathrm{~Pb}$ & 0.1 & 0.0519 & 0.0833 & 0.0298 & 0.0246 & 0.0217 & 0.0105 \\
$\mathrm{Fe}$ & 5.0 & 0.7881 & 0.8212 & 0.5455 & 0.2245 & 0.2400 & 0.2003 \\
$\mathrm{Zn}$ & 5.0 & 0.3144 & 0.1475 & 0.1072 & - & - & - \\
\hline
\end{tabular}


neutralization, winterization, and deodorization stages. Each stage affects the content of toxic elements in purified oil.

The process of oil hydration involves the introduction of a hydrating agent, usually water (sometimes water vapor), at a temperature of $45-65{ }^{\circ} \mathrm{C}$ and vigorous stirring. Having hydrophilic properties, phospholipids and protein substances of oil during hydration intensively absorb water, swell, and enlarge forming flakes that precipitate and are removed [34,35]. The toxic elements can be removed from oil together with the hydration precipitate, as it has been established by the IChP and atomic absorption methods.

The oil neutralization is carried out in order to remove free fatty acids [34-37]. The main alkaline agent for the neutralization is sodium hydroxide. After alkaline neutralization, the soap stock is separated from the oil and the soap residue is washed off. Usually, this process is followed by double rinsing with hot water (the amount of water is $5 . .10 \%$ of oil weight) and additional treatment with a solution of citric acid at a concentration of $10 \%$. At the stage of neutralization, the toxic elements may be removed both during the separation of soap stock and during oil washing.

The winterization process involves the removal of waxy substances by gradual cooling of oil to a temperature of $6 \ldots 12^{\circ} \mathrm{C}$ with a small amount of filter powder. Upon cooling, the waxy substances crystallize on the surface of the powder particles and are separated by filtration. After freezing, the oil becomes transparent and its appea- rance improves. The toxic elements remaining in oil after the previous stages can be removed simultaneously with the wax suspension $[34,35$, and 38].

The purpose of the last technological operation (deodorization) is to remove smell and taste at a temperature of $200 \ldots 240{ }^{\circ} \mathrm{C}$, a residual pressure of $0.2 \ldots 0.4 \mathrm{kPa}$, and supply of dry superheated steam in the amount of $0.5 \ldots 5 \%$ of oil weight. At the stage of deodorization, the highly toxic substances such as 3.4 benzopyrene (content in oils from $0.5 \ldots 15 \mu \mathrm{g} / \mathrm{kg}$ ), organochlorine pesticides, and mycotoxins are removed [34-36]. This is the last stage of the refinement measures, during which toxic elements can be removed.

According to the results of both methods used (Tables 1 and 2), the toxic elements are removed at all stages of the refining process.

Having analyzed sunflower oil obtained by different extraction methods, it is found that the content of toxic $\mathrm{Cd}$ exceeds the MPC in both the pressed (sample 1) and the extracted (sample 2) oil. This can be explained by the fact that the fields for sunflower crops are treated with phosphorus fertilizers for the production of which natural deposits of phosphorus-containing ores that include cadmium compounds are used. The plants absorb up to $70 \%$ of cadmium from the soil and $30 \%$ from the air $[6,8$, and 16$]$.

A significant amount of $\mathrm{Cd}$ is removed during the oil hydration stage, in the subsequent stages of purification its content is significantly reduced and meets the established standards.

Table 2. Concentration of Toxic Elements in Sunflower Oil, as determined by the IChP Method

\begin{tabular}{|c|c|c|c|c|c|c|c|}
\hline Element & $\begin{array}{l}\mathrm{MPC}, \\
\mathrm{mg} / \mathrm{kg}\end{array}$ & \multicolumn{6}{|c|}{ Content of toxic elements, $\mathrm{mg} / \mathrm{kg}$} \\
\hline $\mathrm{Cu}$ & 0.5 & 0.519 & 1.28 & 0.143 & 0.314 & 0.181 & 0.117 \\
\hline $\mathrm{Hg}$ & 0.03 & 0.0067 & 0.0072 & 0.0031 & 0.0023 & 0.0018 & 0.0012 \\
\hline $\mathrm{Fe}$ & 5.0 & 0.7113 & 0.8231 & 0.6456 & 0.2345 & 0.2018 & 0.1908 \\
\hline $\mathrm{Zn}$ & 5.0 & 0.3134 & 0.1772 & 0.0934 & - & - & - \\
\hline
\end{tabular}


At the initial stages of oil production, the content of $\mathrm{Cu}$ also exceeds the maximum permissible concentration. The cause of a high content of the element is its extremely wide distribution in the environment: soil, water, and air. After extraction (sample 2), the $\mathrm{Cu}$ content significantly increases and reaches $1.28 \mathrm{mg} / \mathrm{kg}$, while the maximum concentration limit is $0.5 \mathrm{mg} / \mathrm{kg}$. This can be explained by the fact that solvents stimulate the diffusion of copper. However, in the subsequent stages of sunflower oil purification, the concentration of this element significantly decreases.

The content of mercury, arsenic, lead, iron, and zinc in oil does not exceed the MPC and gradually decreases in the course of its purification.

The obtained data can be the basis for the widespread introduction of the IChP method in refinement, as this method allows determining the content of toxic elements in vegetable oils with a high convergence of results relative to the traditionally used method of atomic absorption.

\section{Conclusion}

1. An important element of the study is the use of modern inversion chronopotentiometry for the analysis of toxic elements at each stage of the technological process of oil production, which allows the control and adjustment of measures to reduce the content of toxic elements at each stage of oil production.

2 . The information on the toxic effects of chemical elements the content of which is controlled in domestic sunflower oil has been generalized. Among them there are extremely hazardous As, $\mathrm{Pb}, \mathrm{Hg}, \mathrm{Cd}$, and those that in certain concentrations are necessary for the normal functioning of the human body ( $\mathrm{Fe}, \mathrm{Zn}, \mathrm{Cu}$ ), but in excessive amount have a negative toxic effect on the body.

3 . The research has clearly shown that the technology for sunflower oil purification in the conditions of oil-and-fat enterprises is effective.

4. It has been established that the methods used for controlling the refinement have a sufficient accuracy and allow determining the content of the full list of toxic elements provided by the regulatory documentation.

5. The IChP method has shown the same test results as the conventional method of atomic absorption, but the former enables determining the content of toxic elements in vegetable oils in a much faster, safer, and more economical way.

\section{REFERENCES}

1. Ukrainian exports of sunflower oil reached $60 \%$ of the world market https://landlord.ua/news/ukrainskyi-eksport-soniashnykovoi-olii-siahnuv-60-svitovoho rynku-stepan-kapshuk/ (Last accessed: 19.05.2020).

2. The main indicators of oilseeds in the first quarter of 2019. URL: http://ukrainian-food.org/uk/post/osnovni-pokazniki-olijnih-kultur-u-i-kvartali-2019-roku (Last accessed: 19.05.2020).

3. Export opportunities of Ukraine. URL: http://agro-business.com.ua/agro/ekonomichnyi-hektar/item/12900-eksportni-mozhlyvosti-ukrainy.html (Last accessed: 19.05.2020).

4. DSTU 4492. (2017). Sunflower oil. Specifications. Kyiv [in Ukrainian].

5. Bordajandi, L. R., Gomez, G., Abad, E., Rivera, J., Fernandez-Baston, M. D. M., Blasco, J., Gonzalez, M. J. (2004). Survey of persistent organochlorine contaminants (PCBs, PCDD/Fs, and PAHs), heavy metals ( $\mathrm{Cu}, \mathrm{Cd}, \mathrm{Zn}, \mathrm{Pb}$, and $\mathrm{Hg}$ ), and arsenic in food samples from Huelva (Spain): levels and health implications. Journal of Agricultural and Food Chemistry, 52(4), 992-1001. https://doi. org/10.1021/jf030453y.

6. Voitsitskiy, V. M., Khyzhnyak, S. V., Danchuk, V. V., Midyk, S. V., Kepple, O. Yu., Ushkalov, V. O. (2019). The infake and migration heavy metals of terrestrial and aquatic ecosystems. Biological Resources and Nature Management, 11(1-2), 59-68 [in Ukrainian]. https://doi. org/10.31548/bio2019.01.007

7. Geng, N., Wu, Y., Zhang, M., Tsang, D., Rinklebe, J., Xia, Y., Lu, D., Zhu, L., Palansooriya, K., Kim, K., Ok Y. (2019). Bioaccumulation of potentially toxic elements by submerged plants and biofilms: A critical review. Environment International, 131, 1-9. https://doi.org/10.1016/j.envint.2019.105015.

8. Whitfield, J. B., Dy, V., McQuilty, R., Zhu, G., Heath, A.C., Montgomery, G. W., Martin, N. G. (2010). Genetic effects on toxic and essential elements in humans: arsenic, cadmium, copper, lead, mercury, selenium, and zinc in erythrocytes. Environmental Health Perspectives, 118(6), 776-782. https://doi.org/10.1289/ehp.0901541. 
9. Codex Alimentarius Commission. Codex general standard for contaminants and toxins in food and feed. (2017). Codex Standard, 193.

10. Antonyak, H. L., Vazhnenko, A. V., Panas, N. E. (2011). Biological role of copper and copper-containing proteins in human and animal organism. Scientific messenger of LNU of VeterinaryMedicine and Biotechnologies, 13(2), 322-331 [in Ukrainian].

11. Gaetke, L. M., Chow-Johnson, H. S., Chow, C. K. (2014). Copper: Toxicological relevance and mechanisms. Archives of Toxicology, 88(11), 1929-1938. https://doi.org/10.1007/s00204-014-1355-y.

12. Roohani, N., Hurrell, R., Kelishadi, R., Schulin, R. (2013). Zinc and its importance for human health: An integrative review. Journal of Research in Medical Sciences, 18(2), 144-157. https://doi.org/10.1007/s00204-014-1355-y.

13. Plum, L. M., Rink, L., Haase, H. (2010). The Essential Toxin: Impact of Zinc on Human Health. International Journal of Environmental Research and Public Health, 7(4), 1342-1365. https://doi.org/10.3390/ijerph7041342.

14. Antonyak, H. L., Solohub, L. I., Snitynskyy, V. V., Babych, N. O. (2006). Iron in humans and animals (biochemical, immunological and environmental aspects). Lviv [in Ukrainian].

15. Spivey, A. (2007). The Weight of Lead: Effects Add Up In Adults. Environmental Health Perspectives, 115(1), A30-A36. https://doi.org/10.1289/ehp.115-a30.

16. Mehrdad, R. R., Mehravar, R. R., Sohrab, K., Moghadamnia, A. (2017). Cadmium toxicity and treatment: An update. Caspian Journal of Internal Medicine, 8(3), 135-145. https://doi.org/10.22088/cjim.8.3.135.

17. Abdul, M. K. S., Jayasinghe, S. S., Chandana, E., Jayasumana, C., De Silva, P. (2015). Arsenic and human health effects: A review. Environmental Toxicology and Pharmacology, 40(3), 828-846. https://doi.org/10.1016/j.etap.2015.09.016.

18. Selid, P. D., Xu, H., Collins, E. M., Face-Collins, M. S., Zhao, J. X. (2009). Sensing mercury for biomedical and environmental monitoring. Sensors, 9(7), 5446-5459. https://doi.org//10.3390/s90705446.

19. Lepri, F. G., Chaves, E. S., Vieira, M. A., Ribeiro, A. S. (2011). Determination of trace elements in vegetable oils and biodiesel by atomic spectrometric techniques-a review. Applied Spectroscopy Reviews, 46(3), 175-206. https://doi.org/ 10.1080/05704928.2010.529628.

20. Matveyko, N. P., Kulak, A. I., Protasov, S. K., Sadovsky, V. V. (2017). Inversion voltammetric determination of heavy metals in vegetable oils. Proceedings of the National Academy of Sciences of Belarus, Chemical series, 3, 38-44 [in Russian].

21. Pehlivan, E., Arslan, G., Gode, F., Altun, T., Musa Özcan, M. (2008). Determination of some inorganic metals in edible vegetable oils by inductively coupled plasma atomic emission spectroscopy. Grasas y Aceites. International journal of fats and oils, 59(3), 239-244. https://doi.org/10.3989/gya.2008.v59.i3.514.

22. Farzin, L., Moassesi, M. (2014). Determination of metal contents in edible vegetable oils produced in Iran using microwave-assisted acid digestion. Journal of Applied Chemical Research, 8(3), 35-43.

23. DSTU ISO 8294:2004 (2006). Animal and vegetable fats and oils. Determination of copper, iron and nickel contents. Graphite furnace atomic absorption method. Kyiv [in Ukrainian].

24. DSTU ISO 12193:2004 (2006). Animal and vegetable fats and oils. Determination of lead content by atomic absorption spectrometry using a graphite furnace. Kyiv [in Ukrainian].

25. Otto, M. (2003). Modern methods of analytical chemistry (V. 1). Moscow [in Russian].

26. Ermachenko, L. A., Ermachenko, V. M. (1999). Atomic absorption analysis with a graphite furnace: A Toolkit for Practical Use in Sanitary and Hygienic Research (Ed. L. G. Podunova). Moscow [in Russian].

27. Kopilevich, V. A., Surovtsev, I. V., Galimova, V. M., Maksin V. I., Mank V. V. (2017). Determination of trace amounts of iodide-ions in water using pulse inverse chronopotentiometry. Journal of water chemistry and technology, 39(5), 289-293. https://doi.org/10.3103/S1063455X1705006X.

28. Melnyk, O. P., Ivanov, S. V., Mank, V. V., Galimova, V. M., Galimov, S. K. (2013, November). Use of inversion chronopotentiometry to determine the content of heavy metals in food. Materials of the international scientific and technical conference: «Quality and safety of food», (13-14 Nov 2013, Kiyv), 18-20. Kiyv [in Ukrainian].

29. Galimova, V. M., Mank, V. V., Surovtsev, I. V. (2009). The essence and advantages of inversion chronopotentiometry techniques in determining the concentration of heavy metals in various media. The scientific issues of Ternopil Volodymyr Hnatiuk National Pedagogical University. Series: chemistry, 16, 33-36 [in Ukrainian].

30. Patent of Ukraine № 55158. Surovtsev, I. V., Galimova, V. M., Babak, O. V. Method of histogram digital filtering of chronopotentiometric data [in Ukrainian].

31. Patent of Ukraine № 56623. Surovtsev, I. V., Martyniv, I. A., Galimova, V. M., Babak, O. V. Device for measuring the concentration of heavy metals [in Ukrainian].

32. DSTU 7670:2014. (2015). Raw materials and food-stuffs preparation of samples. Mineralization for determination of toxic elements. Kyiv [in Ukrainian].

33. Karnaukhov, O. I., Galimova, V. M. (2001). Inversion electrochemical analysis. Theoretical bases of the method of inversion chronopotentiometry. Agricultural science and education, 1-2, 26-28 [in Ukrainian]. 
34. Aznauryan, M. P. (1999). Modern technology for cleaning fats, the production of margarine and mayonnaise. Moscow [in Russian].

35. Arutyunyan, N. S. Kornena, Ye. P., Nesterova, Ye. A. (2004). Refining oils and fats: Theoretical foundations, practice, technology, equipment. St. Petersburg [in Russian].

36. Ma, Y., Shi, L., Liu, Y., Lu, Q. (2017). Effects of Neutralization, Decoloration, and Deodorization on Polycyclic Aromatic Hydrocarbons during Laboratory-Scale Oil Refining Process. Journal of Chemistry, 1, 1-9. https://doi.org/10.1155/ $2017 / 7824761$.

37. Molchenko, S. M., Brodyuk, I. S., Demydov, I. M. (2013). The use of aqueous-alcoholic solution of baking soda to neutralize sunflower oil. NTU "KhPI" Bulletin, 55(1028), 80-85 [in Ukrainian].

38. Zashchepkina, N. M., Markin, M. O., Taranov, V. V., Nakonechnyi, O. A. (2019). Modern techniques of sunflower oil expertise in the technological process of winterization. Applied questions of mathematical modeling, 2(1), 53-65 [in Ukrainian]. https://doi.org/10.32782/2618-0340-2019-3-4.

Received 10.06.2020

Revised 23.07.2020

Accepted 23.02.2021

О.П. Мельник' (https://orcid.org/0000-0002-9177-8904),

В.М. Галімова² (https://orcid.org/0000-0001-9602-1006),

I.Г. Радзієвська ${ }^{1}$ (https://orcid.org/0000-0002-6081-0625),

A.I. Маринін ${ }^{1}$ (https://orcid.org/0000-0001-6692-7472)

${ }^{1}$ Національний університет харчових технологій, Україна, вул. Володимирська, 68, Київ, 01033, Україна,

+380 44289 5472, info@nuft.edu.ua

${ }^{2}$ Національний університет біоресурсів і природокористування України, вул. Героїв Оборони, 15, Київ, 03041, Україна,

+380 44527 8242, rectorat@nubip.edu.ua

\section{ЗАСТОСУВАННЯ МЕТОДУ ІНВЕРСІЙНОЇ ХРОНОПОТЕНЦІОМЕТРІЇ ДЛЯ КОНТРОЛЮ ВМІСТУ ТОКСИЧНИХ ЕЛЕМЕНТІВ У РАФІНАЦІЙНОМУ ВИРОБНИЦТВІ}

Вступ. Україна є одним з провідних світових експортерів соняшникової олії. Важливим показником безпечності $є$ вміст у ній токсичних елементів, який не повинен перевищувати гранично допустимі концентрації. Токсичні речовини, потрапляючи в організм людини, знижують функції окремих систем і органів та призводять до імунодефіцитного стану організму.

До токсичних елементів, за якими контролюються харчові продукти належать купрум (Cu), цинк (Zn), ферум $(\mathrm{Fe})$, кадмій $(\mathrm{Cd})$, плюмбум (Pb), арсен (As) та меркурій (Hg).

Проблематика. Не дивлячись на значний прогрес фізико-хімічних методів аналізу, визначення токсичних елементів у сировині, напівфабрикатах та харчових продуктах є складним та проблемним, а питання розробки методів їх ідентифікації є актуальним.

Мета. Порівняння методів інверсійної хронопотенціометрії (IXП) та атомної абсорбції при визначенні вмісту токсичних елементів в соняшниковій олії на різних стадіях технологічного процесу їі виробництва.

Матеріали і методи. Соняшникову олію, одержану пресуванням та екстрагуванням, та суміш пресової з екстракційною різного ступеня очищення (гідратовану, нейтралізовану, вінтеризовану та рафіновану дезодоровану) досліджено методами IXП та атомної абсорбції. При визначенні концентрації токсичних елементів методом IXП встановлено тривалість інверсії анодного розчинення йонів металів, які попередньо були накопичені у процесі електролізу на поверхні індикаторного електроду.

Результати. Аналіз зразків олії свідчить про те, що всі вони містять токсичні елементи, концентрація яких зменшується на кожній стадії виробництва олії, проте не перевищує допустимих рівнів, регламентованих нормативними документами.

Висновки. Результати дослідження створюють передумови для широкого впровадження методу IXП на рафінаційному виробництві, оскільки цей метод дозволяє визначати вміст токсичних елементів в рослинних оліях з високою збіжністю результатів відносно традиційно застосовуваного методу атомної абсорбції.

Ключові слова: соняшникова олія, стадії виробництва, токсичні елементи, інверсійна хронопотенціометрія. 